\title{
TRAINING OF TECTONIC SKILLS IN ARCHITECTURAL STUDIES
}

\author{
Lada Markejevaitè \\ Dept of Architecture, Vilnius Gediminas Technical University, \\ Pylimog.26/Trakug. 1,LT-01132Vilnius, Lithuania.E-mail: ladmar@ar.vgtu.lt.
}

Submitted 28 Jan. 2008

\begin{abstract}
Tectonic expression of forms maintains the importance developed in architecture for a long time, but changing conditions force it to become more complex and integrate more factors. Tectonics creates preconditions for architecture as a sincretic art. So the tectonic nature of architecture becomes of great interest for the creative process. It becomes meaningful to introduce multiple and diverse problems of tectonics into architectural education.

The creative work of a contemporary architect is stimulated by generation of distinctive architectural forms which are based on the nature of materials, logical adoption of structures and development of artistic appearance. Skills in modelling a tectonic form play an important role in the process of creation a sound architectural form. Therefore, it is worth to improve the methods of teaching and develop tectonic skills in a more effective way.

In the process of education understanding of the interrelation of the main tectonic elements - material, structure and form (artistic appearance) - is developed. It is important to develop tectonic skills during the entire educational process. At separate educational stages different problems of architectural tectonics should be analysed, while interrelation of the main tectonic elements is to be disclosed constantly. Tectonic skills are to be developed simultaneously integrating all the relating disciplines. The educational programs of some schools feel lack of complexity in developing tectonic skills and demonstrate insufficient interdisciplinary connection and the continuity of knowledge. The necessity of a new model of complex studies is evident.

To secure a gradual process of tectonic studies, a complex three-levelled model of acquiring tectonic skills is presented. Each level of the model is characterized by progressive acquaintance with the tectonic form. The first level examines tectonic characteristics in non-architectural objects and is an experimental stage; the second level is cognition of architectural tectonic systems and tectonic features of an architectural context; the third level is interpretation based on the tectonic theme: with the help of artistic appearance, an architectural object is tectonically embodied and made meaningful. The stage of interpretation of a tectonic system is the highest level of training compositional skills which integrates the main study disciplines and intensifies students' artistic intuition.

At each level of the model one of the three main elements of tectonics is emphasized: at the first level - material, at the second level - structure and at the third level - form.

Keywords: architectural education, architectural tectonics, elements of tectonics.
\end{abstract}

\section{Introduction}

The aim of the paper is to share the experience the Faculty of Architecture of Vilnius Gediminas Technical University has gained in looking for possible ways to improve the process of architectural education. Special attention was paid to the development of skills in creating an architectural space while closely relating this educational process with the topic of tectonics and the discipline of Architectural Composition.

\section{Importance of tectonics in the architect's professional career and architectural education}

Tectonic expression of forms maintains the importance developed in architecture for a long time, it doesn't loose its significance, but changing conditions force it to become more complex and integrate more factors. As the architectural theorist K. Frampton points "the unavoidably earth-bound act of building tends to be intrinsically tectonic and tactile in character than scenographic and visual... building is first an ontological presence rather than a re-presentational form......the built is a "thing" rather than "sign" or, more precisely, it is an irreducible mixture of both" (Frampton 1990). The tectonic nature of architecture is of great interest for the creative process. The creative work of a contemporary architect is stimulated by generation of distinctive architectural forms which are based on the nature of building materials, logical adoption of building struc- 
tures as well as search for artistic appearance (form). Tectonics determines preconditions for architecture as a sincretic art. Deeper knowledge of the main tectonic elements (material, structure and form) as well as understanding of influencing factors, creates possibilities to generate meaningful and sensible architecture.

It is significant to introduce multiple and diverse problems of tectonics into architectural education, while fundamentally developing students' comprehension that the main tectonic elements are closely interrelated.

Naturally, the educational systems of most architectural schools are undergoing a certain process of constant improvement and development. It happens in the course of time, in parallel with shifts in architectural ideas and life changes in a broad sense. The Faculty of Architecture of Vilnius Gediminas Technical University is similarly undergoing constant changes. But the last fifteen years, after Lithuania became independent from the soviet system, were marked by extreme objectives, firstly, to look for our independent way and figure out who and where we are after all and, secondly, to turn our face to the rest of the world... This process is diverse, always inspiring and alive, sometimes contradictory: "long jump ahead" and returning back for something might be regrettably "left behind".

During the restructuring process of architectural education in the Faculty of Architecture various ideas are tested. One of the considered possibilities for improving architectural education in the Faculty, systematic and gradual development of skills in creating a tectonically embodied space, is accepted. The aim of the ongoing discussions is to restructure the entire study process in such a way that the disciplines of different fields (architecture, engineering, art, humanities) would be integrated into the whole educational process and harmoniously complement one another. The author of this paper suggests an essential role of tectonics in consolidating the entire architectural study process.

Tectonics is one of the most important aspects in architectural composition and it is one of the basic compositional prerequisites in shaping a physically and artistically embodied space. The author of this paper presents a new model of architectural studies, while considering the existing character of studies in the Faculty (importance of the disciplines of Architectural Composition). Gradual and methodical development of tectonic skills is suggested as a background for a wellbalanced model of architectural studies. The intention is to develop students' comprehension of reciprocal interrelation of the main tectonic elements - material, structure and form (artistic appearance).

\section{Complex theoretical three-levelled model of acquiring tectonic skills}

A complex three-levelled model of acquiring tectonic skills is presented (Fig. 1). It is a system which secures a progressive process of architectural education and comprises three levels. At separate educational stages different problems of architectural tectonics are analysed, while interrelation of the main tectonic elements is disclosed constantly. The interrelation of all the disciplines associated with tectonics is constantly disclosed, each level of the model is introduced as an integral part of the educational process. Here the first level corresponds to the initial study years, the second level - to the intermediate (third) study year, and the third level - to the third/fourth study years. Each level is devoted to certain topics of tectonics and dealing with problems of gradually growing complexity.

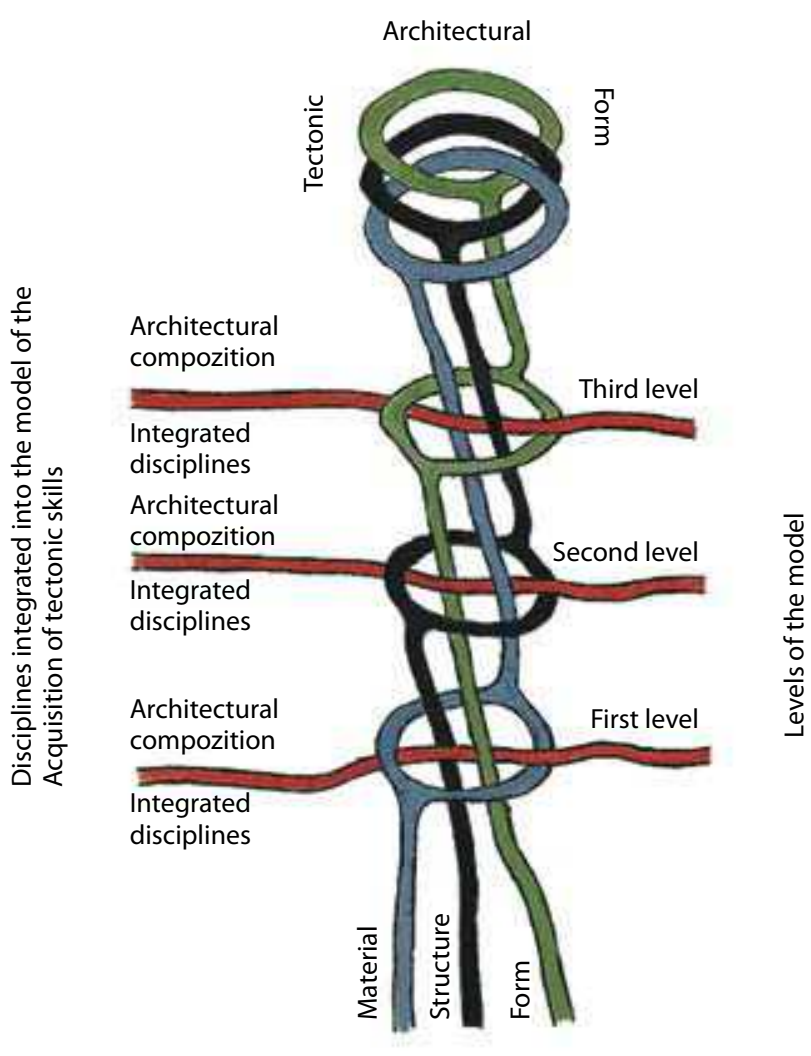

Main elements of tectonics

Fig. 1. Model of acquiring tectonic skills (by L. Markejevaitè). Sketchy drawing 
Disciplines of composition:

"Composition-1" - study of specific regularities of materials (aesthetic aspect. Plastic modelling. Experiments with real materials),

"Composition-II" - study of morphological patterns of bionic (non-architectural) objects, analysis of structural arrangement

\section{Integrated disciplines:}

"Building materials and their resistance", "Use of modular elements in building structures" (use of wood, metal, etc., technical-engineering aspect. "Sculpture", "Basics of industrial design" - (Aesthetic aspect. Modelling from particular materials)

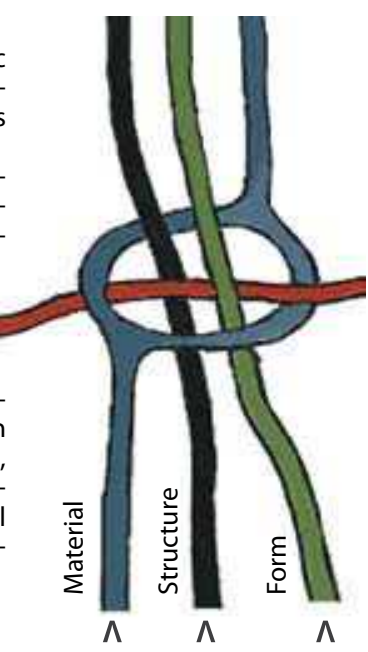

Fig. 2. Position of the main tectonic elements in the threelevelled model. Contents and interrelation of Architectural Composition and integrated disciplines at each level. The first level. Dominant tectonic element - material

At each level of the model the acquisition of tectonic skills is enriched progressively: gradual shift is performed from general aspects towards more complex and problematic ones, requiring critical evaluation. The first level (initial study years), revelation of tectonic characteristics in non-architectural objects (nature, human being, surrounding environment), is an experimental stage and summing-up of the exposed laws (Figs. 2, 3). The second level (intermediate study year), cognition of tectonic systems in architecture and their types, is an analytical stage of studying laws of tectonics (Figs. 4, 5). The third level (third/fourth study years), interpretation of tectonic systems, is the stage of interpretation, the highest stage of developing skills of tectonic treatment of a form (Figs. 6, 7).

The main condition of the proposed study model is to reveal the complexity and wholeness of the tectonics subject. Three levels of the model are dedicated to study interrelation of the three main elements of tectonics simultaneously. Every discipline, which is assigned to develop tectonic skills and is assumed as a part of the proposed model, while being positioned at a certain level of the model, aims to disclose interrelation of all the tectonic elements (material, structure and form). In order to organize the study process fluently, make it more structured and create a common ground for disciplines from different fields "to meet", each level of the model is designated to examine certain aspects of tectonics, and the so-called dominant tectonic element is appointed. The dominant element defines questions

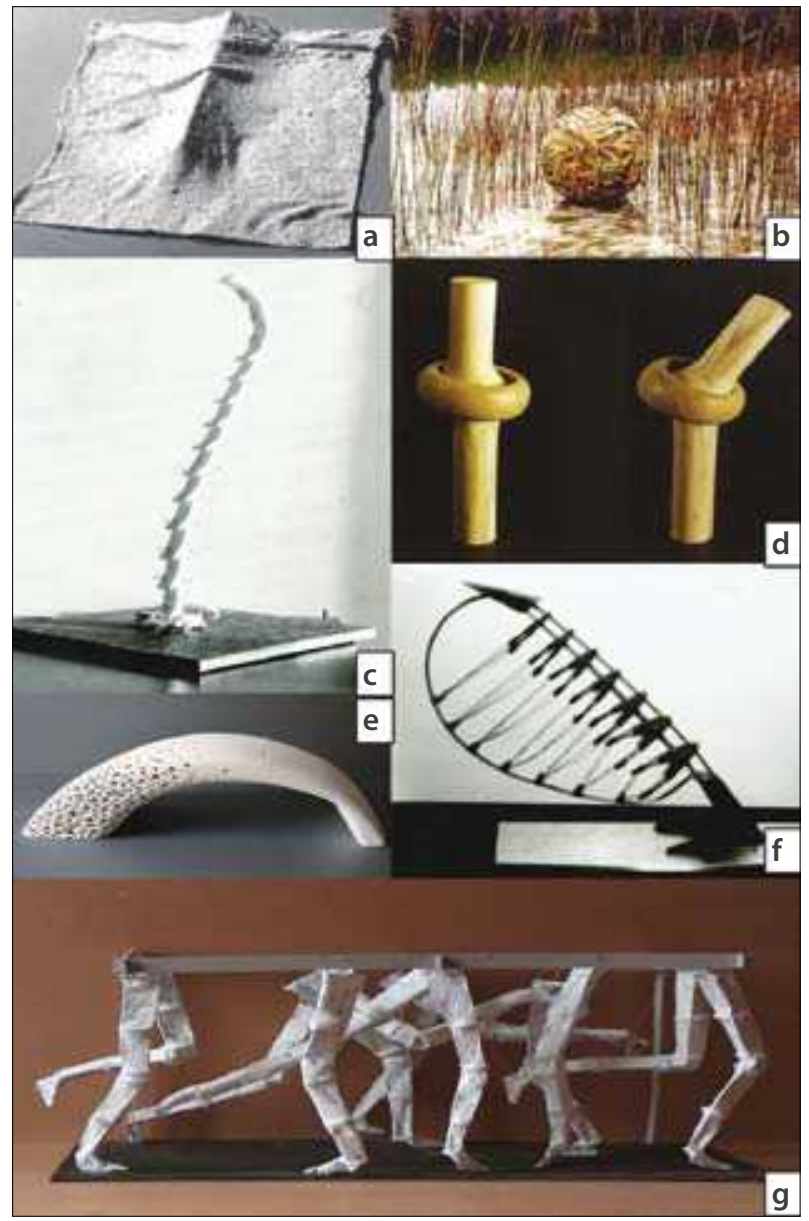

Fig. 3. Examples of students' works. Initial study years: a - study of materials: structured and stiffened textile (VDA); b - study of materials. Exercises on a natural site. Study of modelling possibilities from ordinary natural materials; $d$ - bionic study (VDA); c, e, f - bionic study (VGTU); $g$ - sculptural modelling (VGTU)

to be examined at a particular level (Table). At the first level the material is emphasized, at the second level - the structure, and at the third level - the artistic appearance (form). This could be explained by the following examples: the first level with the assigned aspect of material is mainly devoted to the topics of material, and the remaining two elements (structure and form) complement this topic; for example, structure is examined from the point of view of material: materiality of structures and building technology in natural world. The second level is intended for structure and examination of architectural tectonic systems. Here a subordinate tectonic element of tectonics - material - is analysed as much as it discloses application of materials and their combinations in different tectonic structures, while the other tectonic element - artistic 
Interrelation of tectonic elements in the model. Aspects of tectonics defined at separate levels of the model

\begin{tabular}{|c|c|c|c|c|c|}
\hline \multirow[t]{2}{*}{$\begin{array}{l}\text { Levels of } \\
\text { the model }\end{array}$} & \multirow{2}{*}{$\begin{array}{l}\text { General topics disclosed } \\
\text { at the level. Contents } \\
\text { of architectural compo- } \\
\text { sition and integrated } \\
\text { disciplines }\end{array}$} & \multirow{2}{*}{$\begin{array}{l}\text { Dominant } \\
\text { tectonic } \\
\text { element at } \\
\text { the level }\end{array}$} & \multicolumn{3}{|c|}{$\begin{array}{l}\text { Interrelation of tectonic elements in the model. } \\
\text { Aspect of each tectonic element to be defined in regard to the dominant } \\
\text { element of the level and prevailing topic }\end{array}$} \\
\hline & & & Material & Structure & $\begin{array}{l}\text { Artistic appearance } \\
\text { (form) }\end{array}$ \\
\hline First level & $\begin{array}{l}\text { Materiality and tectoni- } \\
\text { cs of non-architectural } \\
\text { objects }\end{array}$ & Material & $\begin{array}{l}\text { Mechanical properties } \\
\text { of materials, influence } \\
\text { of technological proces- } \\
\text { sing of materials on } \\
\text { modelling pattern }\end{array}$ & $\begin{array}{l}\text { Materiality of structures } \\
\text { and "building technolo- } \\
\text { gy" in natural world }\end{array}$ & $\begin{array}{l}\text { Compositional regulari- } \\
\text { ties of examined form }\end{array}$ \\
\hline $\begin{array}{l}\text { Second } \\
\text { level }\end{array}$ & $\begin{array}{l}\text { Structures and architec- } \\
\text { tural tectonics }\end{array}$ & Structure & $\begin{array}{l}\text { Application of mate- } \\
\text { rials and their com- } \\
\text { binations in different } \\
\text { tectonic structures }\end{array}$ & $\begin{array}{l}\text { Cognition of architectural } \\
\text { tectonic systems }\end{array}$ & $\begin{array}{l}\text { Influence of structures } \\
\text { on artistic appearance }\end{array}$ \\
\hline Third level & $\begin{array}{l}\text { Tectonic embodiment } \\
\text { of architectural idea }\end{array}$ & $\begin{array}{l}\text { Form (ar- } \\
\text { tistic ap- } \\
\text { pearance) }\end{array}$ & $\begin{array}{l}\text { Influence of materials' } \\
\text { characteristics on artis- } \\
\text { tic appearance }\end{array}$ & $\begin{array}{l}\text { Artistic appearance of } \\
\text { complex building struc- } \\
\text { tures and their combina- } \\
\text { tions }\end{array}$ & $\begin{array}{l}\text { Embodiment of artistic } \\
\text { idea through tectonic } \\
\text { presentation }\end{array}$ \\
\hline
\end{tabular}

appearance - is viewed as much as it is programmed by structural nature. The third level is devoted to the topic of form (artistic appearance) and mainly reveals embodiment of artistic idea appearance through tectonic presentation. The remaining subordinated tectonic elements complement the predominant topic and add a specific aspect.

At the initial stage it is useful to use students' individual pre-educational experience and senses, to apply the method of experiments and discovery. It is essential to encourage practical exercises with the use of materials and technological process, promote craft as the basic part of architecture. In order to ensure a proper learning process of constructing form, it is very useful to arrange the study process in such a way that the properties of building materials, building techniques are discovered directly by hands, learned by personal experience of students themselves (Markejevaitè 1998). The importance to measure the world (architecture) by body itself is argued in its favour by J. Pallasmaa in his book: "The sense of self, strengthened by art and architecture, allows us to engage fully in the mental dimensions of dream, imagination and desire. ...We feel pleasure and protection when the body discovers its resonance in space. When experiencing a structure, we unconsciously mimic its configuration with our bones and muscles..." (Pallasmaa 2005). The idea is that a deep knowledge and sensibility for material nature is easier acquired through a direct work with materials themselves. Acquaintance with materials, their modelling possibilities and technological processes is systematically revealed in the sculptor's J. Burneika book "Form. Composition. Design" (Burneika 2002) where the author summarized his long-year teaching experience at Faculties of Architecture and Industrial Design in Vilnius Academy of Arts. At the first level the study of tectonic principles in non-architectural objects may vary from analysis of non-alive nature (water, sand, snow, rocks, formations of the macro- and micro-world, etc.) to the study of alive nature (animals, plants), it may encompass the study of non-architectural objects (and various technologies) produced by humans as well as examination of the peculiarities of animal building techniques. The latter topic is of great interest, as it is concerned with essential knowledge inscribed in the life of the whole nature. The architect J. Pallasmaa nicely introduced the study of animal building techniques into architectural education at Helsinki Technical University and demonstrated that animals' building activities could be of great interest for architectural research (Pallasmaa 1995).

At the intermediate level the principles of tectonizing architectural forms are successively studied, including the characteristics and applications of building materials, characteristics of technological processing and choice of building structures as well as preconditions for creating artistic quality.

At the third level of the model students are asked to use their acquired knowledge of art, humanitarian and engineering disciplines and extensively use the 
Disciplines of composition:

"Composition-III" - characteristics of architectural tectonic systems: evolution, compositional analysis. Compositional interpretation of tectonic "Node".

"Composition-IV" - tectonic peculiarities of architectural context and inserted object

\section{Integrated disciplines:}

"Building structures" - peculiarities of structures (various materials) and their adoption for modelling form. Transformable structures; "Mechanics" - performance of complex structures; “Complex architectural design" - integration of tectonic elements into complex statial arrangement; "Architectural history" -historic overview of tectonic culture; "Building practice" - live analysis

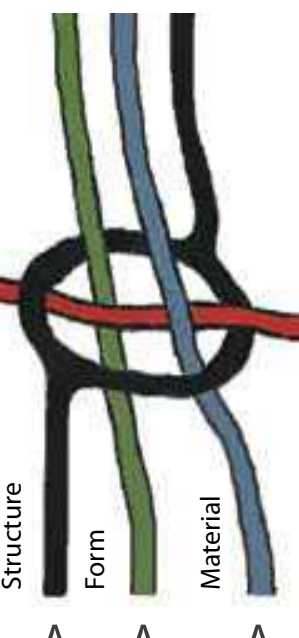

$\Lambda$

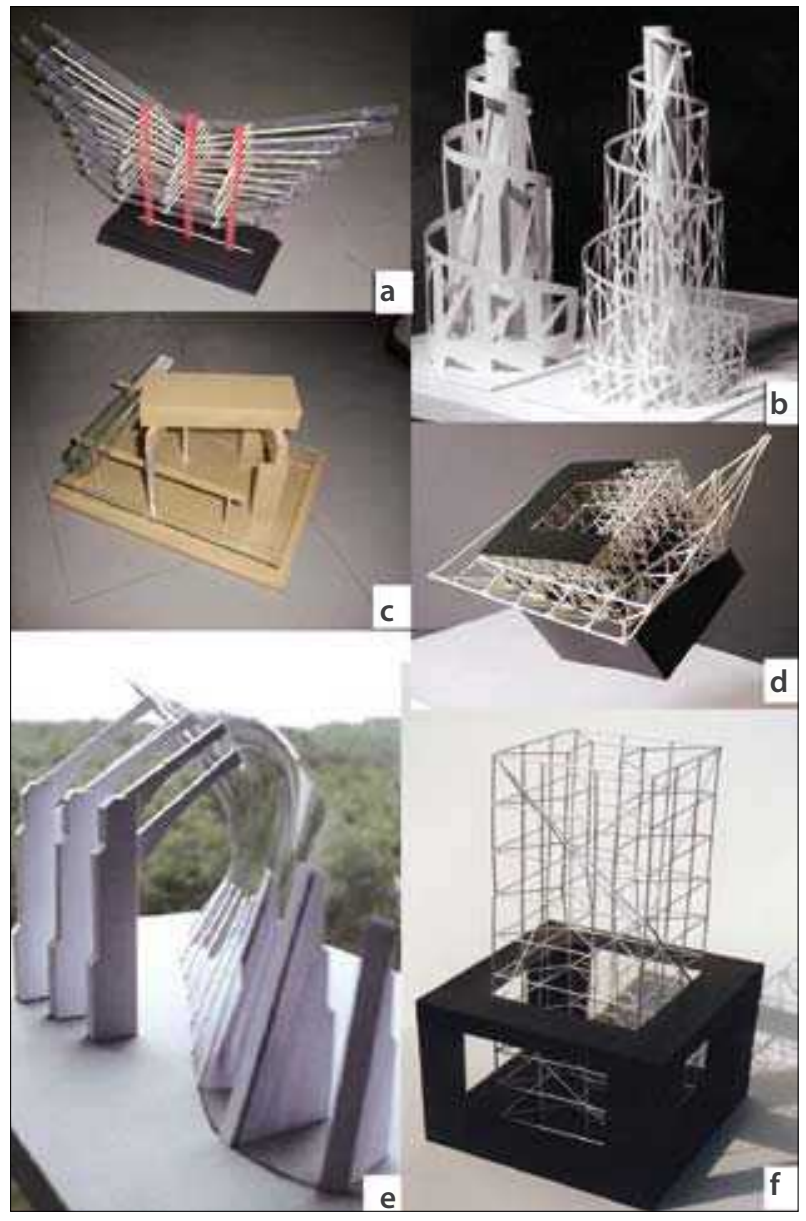

Fig. 5. Examples of students' works. Intermediate study year: a, c - f - architectural tectonics (VGTU); b - study of architectural context and scale (VGTU)

At the first level the discipline "Architectural Composition-I" is designed to study the specific peculiarities of materials, meanwhile the integrated disciplines complement the topic with both - theoretical and practical work - "Building Materials and their Resistance" examines the "qualities of materials", Technology of Building Materials contributes with practical exercises and examination of technological processes, "Sculpture" introduces studio work and modelling from a real material as well as examination of plastic properties (Fig. 2).

At the second level "Architectural Composition-III" (Study of Architectural Tectonics) is complemented by the disciplines "Building Structures" where the peculiarities of structures and comparison of different materials are concerned as well as transformable and complex structures are analysed, laboratory exercises are intended for building and testing the study model of a chosen 
Disciplines of composition:

"Composition-V" - composition and interpretation of urban structures. Tectonic composition of urban pattern. "Composition-Vl" - structural analysis and compositional interpretation of architectural object. Correspondence of artistic pattern and structural system

Integrated disciplines:

"Architectural semantics and psychology" - tectonic embodiment of architectural language.

"Creative methods" improvisation. Artistic/technical creative process

"Building structures" correspondence of structural pattern
혼

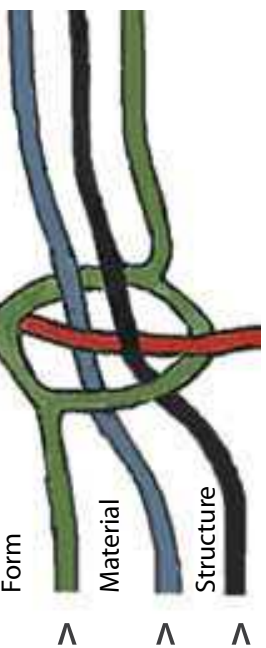

Fig. 6. Position of the main tectonic elements in the threelevelled model. Contents and interrelation of Architectural Composition and integrated disciplines at each level. The third level. Dominant tectonic element - form

spatial structure, "Mechanics" analyses the performance of complex structures, "Architectural History" enriches the topic with an overview of the evolution of tectonic culture, "Building Practice" is committed to live analysis and experimental modelling of structural nodes to scale 1:1 (Fig. 4).

At the third level the disciplines of Compositions and assigned topic of compositional interpretation and tectonic embodiment of an idea is complemented by theoretical and practical work of "Architectural Semantics and Psychology", "Study of Creative Methods" and a deeper analysis of the newest tendencies in the practice of building structures introduced by "Building Structures" (Fig. 6).

The disciplines, which are integrated in the model, are "chained" with one another through a certain aspect of tectonics.

\section{Conclusions}

The aim of architecture is to create a space by applying certain materials, structures and a logically developed artistic form.

While developing the proposed model of acquiring tectonic skills, it was aimed to encourage students to avoid mannerism and weakness of form and, instead of emphasizing simply visual characteristics of architecture, to comprehend truthful possibilities of a tectonically embodied space.

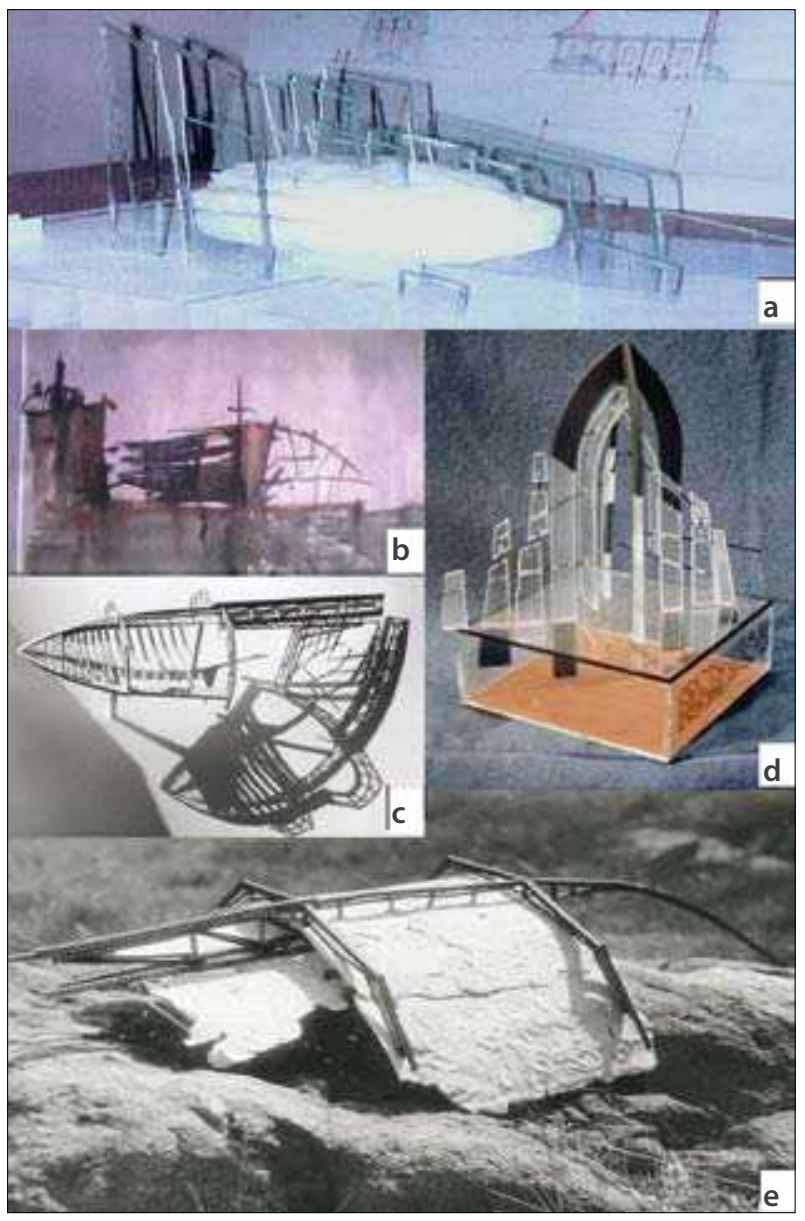

Fig. 7. Examples of students' works. Third/fourth study years: a, d - study of structural analysis and compositional interpretation (VGTU); b, c, e - tectonic interpretation of urban pattern (VGTU)

The paper assumes the essential role of tectonics in consolidating the whole architectural study process and creating a common background for the use of disciplines from various fields. Different disciplines become interrelated via the tectonic subject and harmoniously complementing one another.

\section{References}

Burneika, J. 2002. Forma. Kompozicija. Dizainas. [Form. Composition. Design]. Vilnius: VDA leidykla.

Frampton, K. 1990. Notes on the scope of the tectonic, in Paper presented in Baltic Architecture Biennale, Tallinn, 199009.

Markejevaitè, L. 1998. Trumpų užduočių vaidmuo studijų procese [The Role of Short-Term Tasks in Study Process], Urbanistika ir architektūra 22(3): 100-105.

Pallasmaa, J. 1995. Architecture of the Essential, Estonian Architecture Review 12: 53-59; 13: 46-59.

Pallasmaa, J. 2005. The Eyes of the Skin. Architecture and the Senses. UK, Willey Academy, 11, 67. 


\section{TEKTONIZAVIMO İGŪDŽIŲ UGDYMAS ARCHITEKTŪROS STUDIJOSE}

\section{Markejevaitė}

Santrauka. Per ilgą laiką susiformavusi tektoninè formų raišska išlieka svarbi architektūroje ir šiais laikais, tačiau kintant gyvenimo sąlygoms tampa kompleksiškesnè ir integruojanti daugiau raiškos aspektų. Tektonika sukuria prielaidas architektūrai reikštis kaip sinkretiniam menui - taigi tektoninio formos pavidalo paieška atsiduria kūrybinio proceso dèmesio centre. Atsirado poreikis daugialypę, ivvairiapusę tektonikos problematiką įtraukti ị architektūros studijas - tektonizavimo igūdžių ugdymo procesą. Kūrybinis šiuolaikino architekto darbas yra ikvèptas išskirtinių architektūrinių formų, kurios yra pagrịstos medžiagų prigimtimi, logišku konstrukcijos panaudojimu ir meninès raiškos sukūrimu. Formos tektoninio modeliavimo igūdžiai yra svarbūs kuriant visapusiškai užbaigtą architektūrinę formą. Todèl svarbu patobulinti mokymo metodus ir ugdyti tektoninius igūdžius efektyvesniu būdu. Mokymo procese formuojamas trijų tektonikos elementų tarpusavio ryšio supratimas - medžiagos, konstrukcijos ir formos (meninès raiškos). Svarbu ugdyti tektonizavimo igūdžius viso mokymo proceso metu. Skirtingose pakopose turi būti analizuojamos vis kitokios architektūrinès tektonikos temos ir nuosekliai atskleidžiamas tektonikos elementų tarpusavio ryšys. Tektonizavimo gebėjimai turi būti ugdomi vienu metu integruojant visas su juo susijusias disciplinas. Kai kurių aukštujų mokyklų mokymo programoms trūksta kompleksiškumo, nepakanka tarpdisciplininio ryšio ir žinių perimamumo, todèl naujo mokymo modelio poreikis yra akivaizdus. Siekiant užtikrinti nuoseklų tektonikos studijų procesą, pateiktas kompleksinis trijų pakopų tektonizavimo igūdžių ugdymo modelis. Kiekviena kompleksinio tektonizavimo igūdžių ugdymo modelio pakopa skiriama formos tektonizavimo igūdžiams ịtvirtinti skirtinguose lygmenyse. Pirmoji pakopa - tektoninių ypatybių atskleidimas nearchitektūriniuose dariniuose - galètų būti apibūdinta kaip eksperimentinis etapas, antroji pakopa - architektūros tektoninių sistemų tipų ir jų raidos pažinimas, trečioji pakopa - tektoninių sistemų interpretavimas kaip meninès interpretacijos, pagrịstos tektonikos tematika, etapas: meninès raiškos priemonėmis objektas yra tektoniškai ịkūnijamas ir ịprasminamas. Interpretavimo pakopa yra aukščiausia kompozicinių gebejjimų i tvirtinimo pakopa, kuri integruoja studiju disciplinas ir sustiprina studento meninę intuiciją. Kiekvienoje modelio pakopoje yra akcentuojamas vienas iš trijų pagrindinių tektonikos elementų: pirmojoje - medžiaga, antrojoje - konstrukcija, trečiojoje - forma.

Reikšminiai žodžiai: architektūros studijos, architektūrinè tektonika, tektonikos elementai.

\section{LADA MARKEJEVAITÉ}

Doctor of the Humanities (arch.) (since 2003), Assoc Prof, Dept of Architecture, Vilnius Gediminas Technical University (VGTU), Pylimo g. 26/Traku g. 1, LT-01132 Vilnius, Lithuania E-mail:ladmar@ar.vgtu.lt

First degree in Architecture, VTU (now VGTU), 1992. Probation: studies at Academia Istropolitana, Institute of Advanced Studies, Bratislava, Slovakia, in the program "Architectural and Urban Heritage Conservation", 1992-1993. Research interests: architectural tectonics, architectural composition and preservation of architectural heritage. 